\title{
Concept Mapping for Improving Expository Writing in Second Language
}

\author{
Rehana Rahman* \\ Munazza Ambreen ${ }^{* *}$
}

\begin{abstract}
Out of the four language skills, writing is considered to be the imperative one from academic point of view. The students at intermediate level need to practice expository essay writing to be able to write fluently in their university stage ahead. The study investigated the effects of concept mapping strategy on expository writing skill of the students at intermediate level. The study was experimental in nature with pretestposttest control group design. To this end, forty students from Government Girls Higher Secondary School from Intermediate Part II were selected as an average sample after their Proficiency in English Language Test (PET). They were divided into two equivalent groups after pretest. The concept mapping treatment was given to the experimental group for six weeks. They composed 10 expository essays following concept mapping strategy for each essay. The control group was taught in a conventional way. Pretest-Posttest score difference of writing achievement of control and experimental groups revealed significant difference. It was observed that the he treatment group wrote more organized, extensive, comprehensive and rich essays than those written by students of control group. The findings suggest that concept mapping is a practical tool in prompting expository writing skill of the students at intermediate level in Pakistani perspective.
\end{abstract}

Keywords: concept mapping, expository writing skill, intermediate, strategy, proficiency in English test (PET)

\footnotetext{
*Ph.D Scholar, Allama Iqbal Open University, Islamabad, Pakistan Email: Rehanaanjum35@yahoo.com

** Assistant Professor, Allama Iqbal Open University, Islamabad, Pakistan Email: munazza.ambreen@aiou.edu.pk
} 


\section{Introduction}

Concept mapping is a valuable strategy to encourage learning with a primary goal (Novak \& Gowin, 1984). Based on Ausubel's theory of assimilation and constructivist ideas, concept mapping strategy can be applied on developing different skills. Ausbel (1963) suggests that learning takes place by the assimilation of new concept based on the existing knowledge. The framework that a learner holds is called cognitive structure. Novak and Gowin (1984) have described concept mapping as a creative task of identification of concepts, their relationships and then their structure within a specific knowledge domain. Among the four basic language skills, reading and writing are considered important ones from academic point of view. Writing is a complex skill that involves higher level of cognitive activities (Negari, 2011; Rao, 2007). Students at the intermediate level are required to develop writing skill that may enable them to plan, outline, draft, summarize, compose and revise the material. All other skills of listening and reading are also inter-related to writing skill (Saed \& Al-Omari, 2014). Other abilities like summarization, analysis and criticism are also stimulated by writing activity by emphasizing the constant reflection in target language (Maghsoudi \& Harrison, 2013). Therefore, it is widely tested in examinations. In Pakistan, it has occupied an important place in examinations. The skill of writing needs some strategies to be helpful and supportive for its development. There is a vast variety of teaching strategies being employed making a tough choice for students to make. Therefore, students find themselves uncertain about many cognitive and linguistic strategies helpful in writing task (Maghsoudi \& Harririan, 2013). The basic problem of students in writing is their inability to generate and link ideas by organizing them in paragraphing (Farmansyah, 2015). The researcher herself considered concept mapping as helpful strategy in this regard. For the development of this vital language skill, some important teaching learning strategies can be required for improvement especially at the intermediate level when the students undergo a critical period of selection for their career education, and after passing intermediate seek admission in colleges and universities in their relative fields (Siddique, 2010).

The concept mapping is considered one of the effective strategies in teaching writing skill. A concept map represents the relationship of ideas connected around central theme (Deshatty \& Mokashi, 2013). Thus, it is effective tool in helping the students to organize information for writing by associating ideas, linking concepts and developing thinking skill by 
establishing logical relationship with ideas (Buzan, 2010). The concept mapping may be utilized to initiate knowledge former to composing and to frame students' memory in all stages of the writing process by supporting students to perceive word, concept, and group relationships. The concept mapping has been used in a diversity of classroom presentations for vocabulary development, study skill improvement, reading comprehension, and prewriting organization.

Concept maps can be applied in actual phase of instruction at any stage of unit or lesson as before, during and after activities. Concept maps can be used at introductory stage of a lesson to set a new material. During lesson, teacher may use concept map in conjunction with introduction and place the map in the class for reference of the students as the lesson progresses. The students may augment and enlarge the concept map as the lesson develops. This augmentation can be done at individual as well as group level. A copy of an overall unit's concept map may be given to the students by the teacher to revise and summarize the whole unit's key points (Bharambie, 2012; Muhib, Anggani \& Hortono, 2014). The concept map developed in a class in such a way may be like a bowl of spaghetti that is understood only by the students of the class and no one from the outside. Another application of concept map is drawn by the students themselves. They build up on their own ideas what to be studied in a unit. On the whole the map gives direction to the study area content of the unit as decided by the students. Concept maps give the students an opportunity to think about ideas and their connections about the subjects being studied and the meanings of different terms enable the students to organize and learn effectively and store and retrieve the learnt material more efficiently. Vanides, Yin, Ruiz-Primo, Ayala and Shavelson (2005) present two ways the concept maps can be conducted while teaching science at middle standard. First is to teach the students the construction of concept maps by the students themselves about the unit to be studied and the second is the use of teachers' made concept map for the introduction of unit, definition of terms and the interrelationship of different concepts. Whatever the application of concept map is, either constructed by students or by teachers help students to understand and internalize the scope of learnt material and to comprehend how different aspects and key points are integrated to make a whole unit connected.

Literature notifies that the benefits of concept mapping for information organization, learning assessment, comprehension of communication and understanding of a text (Keles, 2012). There is an ample verification for the usefulness of the utilization of concept 
mapping strategy in writing tasks. Research tells that concept mapping effects positively on academic writing. The concept mapping in writing help students to:

- Organize ideas and understand the written information easily

- Develop ideas effectively by making writing an easy process

- Develop understanding and elaborating topic easily

Literature reports another use of concept mapping in writing. For example, Ojima (2006) applied concept mapping as an instructional strategy tool for development of writing at its planning stage. The findings revealed that in English class the learners produced better results with the help of concept mapping. Same results were also shown by (Fahim \& Rahimi, 2011; Kyoko \& Hiroko, 2011;Pishgadam \& Ghanizadeh, 2006). The students learning foreign language for several years when feel unable to express themselves in clear and well-organized way, they need some comprehensible strategy to improve their writing power. Pishghadam \& Ghanizadah (2006) report some problems in writings of students which include organization and sequencing of ideas, strong thesis and relationship between ideas. As these problems are addressed at planning stage, the stage occupies an important role to support learners in organization of ideas, setting of objectives and construction of linkage between concepts. The concept mapping thus can be used as visual representation of ideas in a creative way at different stages in writing development.

\section{Review of Previous Studies on Strategy Instruction and Concept Mapping}

Strategy instruction includes all the activities a teacher performs in order to transform knowledge to the active learners by educating and training them how to learn and then apply learned material in their day to day lives outside the classrooms. Students are required to do a lot of practice to integrate newly received information with previous knowledge and then to retrieve information any time it is needed. The skillful teachers adopt and employ careful use of strategies to reach the goal. Brown (2000) urged teachers to use effective strategies in various academic settings as a learner centered approach.

The effects of strategy instruction on language learning have gained increased attention in English language teaching. Chen (2007) concluded that language proficiency is promoted by strategy training and the 
learning process is modified actively. In another study, Lin, Strickland, Ray and Denner (2004) compared computer based strategy of concept mapping with paper pencil concept mapping strategy. He investigated concept mapping as pre writing strategy for students at middle school level. The results revealed that computer based concept mapping was effective to generate ideas at pre-writing stage for development of persuasive writing than paper pencil concept mapping.

Vakilifrd and Armand (2006) investigated the impacts of instructional strategy of concept mapping devolution on comprehending informative text in French as a foreign language. The results verified that the traditional approach did not yield better results with control group. Similarly, Liu, Chen, Chang\& Yu-Ju (2010) investigated the effects of Computer Assisted Concept Mapping Strategy on reading comprehension of students at College Level. The study yielded the results that the students with low level group had more reading effects than high level group students in enhancement of reading skills as listing, reading, enforcing and reviewing.

An experimental study by Ahangari and Behzady (2011) investigated computer mediated concept mapping as explicit strategy on writing skill of EFL Iranian students. The components of writing studied were: content, vocabulary, organization, mechanics and language use. The results indicated the significant influence of concept mapping on writing skill in general and in particular following the rubric. Again in another study on Iranian students at university level was conducted by Fahim and Rahimi (2011) to see the effects of concept mapping on writing skill. The difference in mean score of pretest and posttest revealed that students of experimental group performed better than those of control group.

In Korean writing classes, effects of collaborative concept mapping instructional strategy on students' engagements in communicative interaction were seen by Lee and Cho (2010). The findings revealed that students not only improved their writing skill but also enhanced skills in organization, vocabulary and conventions. In Korea again, Lee (2013) investigated the effects of concept mapping strategy in a course module on learning engagements in collaborative planning of students learning Korean language. There were three writing sessions to collect data i.e. pretest, individual planning and collaborative planning. The results indicated that concept mapping facilitated the planning process of writing to help L2 learners resulting in improved composition scores. The improvement in writing was because of implementation of peer collaboration to construct concept maps. 
These evidences from past studies revealed that concept mapping as instructional strategy was applied to see results with reference to language skills of the students. Thus a strong foundation for present study emerges. The present study is different from previous studies as it investigated the effects of concept mapping on expository writing skill of the students whereas in previous studies, writing compositions were studied with this particular strategy only in argumentative, persuasive and descriptive forms. To fill the gap, the present study aimed to investigate the efficiency of this instructional strategy on Pakistani intermediate students.

\section{Research Questions}

The formulated research questions for the study are given as under:

i. What level of English language proficiency do students possess at intermediate level?

ii. What level of expository writing skill proficiency do the students possess at intermediate level?

iii. Is concept mapping strategy supportive in improving expository writing skill?

\section{Methodology}

\section{Design}

The study is experimental to find the effect of concept mapping on the expository writing skill of the students at Intermediate Level. In Pretest Posttest Control Group Experimental Design, there was one experimental and one control group. Gay (1995) recommended experimental design to control nearly all sorts of threats to internal and external validity. The Control and experimental groups participated in pretest and posttest but only the experimental group received the treatment through intervention course.

Symbolically the research design, i.e., Pretest Posttest experimental control group design was:

$$
\begin{aligned}
& \mathrm{R} \rightarrow \mathrm{O}_{1} \rightarrow \mathrm{X}_{1} \quad \rightarrow \quad \mathrm{O}_{2} \quad \text { Control } \\
& \mathrm{R} \rightarrow \mathrm{O}_{1} \rightarrow \mathrm{X}_{2} \rightarrow \mathrm{O}_{2} \quad \text { Experiment } \\
& \text { Where: } \\
& \mathbf{R}=\text { Random sampling of subjects into group } \\
& \mathbf{O}_{1}=\text { Pretest }
\end{aligned}
$$


$\mathbf{X}_{1}=$ Treatment of control group through traditional method

$\mathbf{X}_{2}=$ Treatment of Experimental group through contextualization to improve Expository Writing Skill

$\mathbf{O}_{2}=$ Posttest

The experiment was conducted in randomly selected Government Girls Higher Secondary School, City D. G. Khan. The experimental group was taught through employing concept mapping strategies whereas the control group received instruction through traditional lecture method.

\section{Participants}

The target population of study was the students of Dera Ghazi Khan. In this division, there are in total 18 Government Girls Higher Secondary Schools with number of students enrolled in Inter Part II, 1607. Data of population is presented in table 1 .

Table 1

Distribution of Intermediate Level Learners' Population in Public Sector Higher Secondary Schools, Dera Ghazi Khan Division

\begin{tabular}{lllllc}
\hline District & $\begin{array}{l}\text { No of Girls } \\
\text { Higher Sec. } \\
\text { Schools }\end{array}$ & $\begin{array}{l}\text { No of Students } \\
\text { (Girls) } \\
\text { Part I }\end{array}$ & $\begin{array}{l}\text { No of } \\
\text { (Girls) } \\
\text { Intermediate Part II }\end{array}$ & Total \\
\hline Dera Ghazi Khan & 6 & 1,115 & 951 & 2066 \\
Muzafar Garh & 5 & 506 & 360 & 866 \\
Rajan Pur & 5 & 553 & 206 & 759 \\
Layyah & 2 & 89 & 90 & 179 \\
(Total) 4 & 18 & 2,263 & 1,607 & 3870 \\
\hline
\end{tabular}

Source: School Education Department, Government of Punjab (Census of Schools)

One Higher Secondary School was taken randomly from target population. It was Government Girls Higher Secondary School, City D. G. Khan. Total Enrolled students in school were 102 out of which two left. 100 students were given writing skill proficiency test and 40 students were selected as an average sample to make one control and one experimental group, each comprising of 20 students. In Experimental studies, the minimum number of subjects in each group must be 15 (Gay, 1995). 


\section{Instrumentation}

Pretest-posttest control group design was used for experimental study and data was collected through tools of pretest and posttest. Later these tests were evaluated using rubric.The instruments employed in the whole study were:

1. Preliminary English Test (PET) Writing Part

2. Intervention Course

3. Pretest-Posttest

\section{PET}

To investigate the writing proficiency level of the students, an English language proficiency Test i.e PET was adapted offered by Cambridge. A full sample paper of PET can easily be downloaded from www.CambridgeESOL.org for which no prior permission is required. Preliminary English Test (PET) is a test at intermediate level qualification. It is an international test of Cambridge English. This test comprises of three parts: Reading and Writing, Listening, Speaking. Reading and Writing Part is of 1 hour and 30 minutes. Writing part consists of three parts which are designed to assess students' ability of comprehension and production of written English fluently. The researcher selected and adapted only Writing Part of PET to test students' writing ability. The structure of the test is framed in three parts as followed:

Part one is about sentence formation. Part two is developed to assess students' ability to write a short communicative message that can be in the form of E-mail, note or a postcard. Part three demands the students to write a longer piece of writing. Two questions are given and the students have to do one question only. One is about story writing and other is writing an informal letter. The test has been adapted from a standardized test, so the validity and reliability has already been maintained.

\section{Intervention Course}

The intervention course for teaching expository writing skill was developed consisting 10 prompts on concept mapping. The control group was taken pretest, posttest but it was not the part of the writing prompts. The control group was only given 10 topics to write essays as per traditional method. All the topics were taken from level of Intermediate 
and recommended syllabus of the Board of Intermediate and Secondary Education (BISE). Intervention course was developed keeping learners' need and the cognition level of the students a point of focus. The vocabulary was selected with care in accordance with familiarity level of the students. The researcher avoided the difficult or ambiguous vocabulary while developing writing prompts. The topics were made clear concept mapping prompts. All the ten topics were of Expository Writing Essays with various categories as listed below:

Table 2

Topics Selected for Expository Writing Skill (10 Topics)

\begin{tabular}{lll}
\hline Expository Writing Variation & \multicolumn{2}{l}{ Topics } \\
\hline Description & 1. An Ideal Student \\
Narration (Sequence) & 2. My Hobby \\
& 3. A visit to Historical Place \\
Comparison & 4. A Picnic Party & \\
& 5. City Life and Village Life \\
Cause and Effect & 6. Science: A friend or a foe of Man \\
& 7. Effects of Unemployment on Pakistani \\
& & Economy \\
Explanation & 8. Effects of Information Technology on Education \\
& 9. Why I love Pakistan & \\
& 10. Our Examination System & \\
\hline
\end{tabular}

The intervention lasted for six weeks. The control group received no treatment through concept mapping and was taught expository writing skill in traditional way. The experimental group received the treatment through instruction and practice in concept mapping under the following phases presented by Harris and Graham (1996) cited in Talebinezhad (2007):

i. Strategy Description

ii. Discussion of goals and purposes

iii. Modeling the strategy

iv. Students' mastery of Strategy steps

v. Guided practice and feedback

The model for teaching expository writing through concept mapping was instructed in the following way:

\section{a. Strategy Description}

A concept map is representation of ideas in a graphical ways. The concepts are linked and labeled through arrows or lines to show interrelationships between terms. Concept maps are used as learning 
tools to organize material, plan skills, understand concepts, revise for exams and share knowledge in a systematic way. To follow writing through concept map, understand following hints:

- Identify general topic.

- Brainstorm topic and key terms

- Connect and organize all concepts.

- Practice writing using concept maps.

\section{b. Discussion of Goals and purposes}

Ask students:

- How would concept map help you to write?

- How would you write different types of writing using this strategy?

c. Modeling the strategy:

Creating concept map collaboratively on board and practice writing

\section{d. Students Mastery of Strategy Steps}

Rehearsal of following concepts and links by students and monitoring by teacher

\section{e. Guided Practice and Feedback}

Practice of writing essay by students and feedback by the teacher on students writing following concept maps.

The experimental groups got treatment for six weeks, each group 4 sessions per week (40 minutes each). The first four sessions were devoted to training of the concept mapping strategy and the next 20 sessions were devoted to practice the strategy for the development of target proficiency. One essay was composed for every two sessions of one week for a total of ten essays per student. The writing practice was an individual practice. The essays were corrected following the rubric and returned to the students. A separate mark list was prepared for individual essay judgment. The control group was taught in a conventional way during the same time period. All the groups were taught by the same teacher, the researcher herself. The researcher is the actual teacher of the class so the researcher has already very good relationship with the subjects. As the subjects were asked about their consent to carry on the task, the threat of unequal power relation was controlled. To ensure the objectivity of researcher while teaching through a particular technique, a demonstration in front of three experts was given. They ensured the validity of technique so that the teacher may not 
mingle up techniques. Scoring of each activity of intervention course was done by the researcher.

\section{Pretest-Posttest}

For experimental design, pretest and posttest were developed to measure the performance of the students at the beginning and at the end of experiment. Since Intervention course was developed to teach expository essays, pretest and posttest also consisted of expository essay writing topics. The students were required to write 5 paragraphs (350400 words) on the situation about an accident. 20 minutes were for brain storming session and one hour for writing essay was given to the students. The paragraphs were mapped as introductory paragraph, three body paragraphs and one ending paragraphwith hints like:

- Topic

- Introduction (who, what, when and where)

- Body Paragraph (First witnessed...)

- Body paragraph (Next...)

- Body paragraph (then...)

- Conclusion (Finally reflect on total event)

Requirement: Now write an essay on an accident explaining your principal about what happened to your class-fellow on the way to school. Posttest was developed to measure the performance of the students at the end of experiment. It was designed parallel to the pretest. The students were required to write an expository essay on 'Co-Education' consisting of 350 to 400 words and to follow the map with hints like:

- Topic

- Introduction (what does it mean?)

- Body Paragraph (Benefits of Co-Education)

- Body Paragraph (Harms of Co-Education)

- Conclusion

Requirement: Now write an essay on Co-Education considering its pros and cons for our society.

\section{Data Analysis}

Data Analysis was carried out using Statistical Package for Social Sciences (SPSS) software version 20 on computer. Inferential and 
descriptive statistics tools were also used to analyze numerical data (descriptive statistics, t-test to compare mean scores).

\section{Rubric for Marking Essay}

Scoring of pretest, posttest and each expository essay writing activity of intervention course was done following four aspects emphasized in rubric.

i. Content/ understanding of the topic

ii. Development of Ideas

iii. Paragraph organization/ Essay Organization and Coherence

iv. Convention/grammar/mechanical/sentence structure

The rubric was adapted from National Curriculum for English Language, Grade I-XII by Federal Ministry of Education (2006).

\section{Results}

The results of the study are as followed:

\section{Results of Preliminary English Test (PET) Before Experimentation}

The experiment was carried out in Government Girls Higher Secondary School, City D. G. Khan. The students were taken from Intermediate Part II session 2014-2016. To ensure the first research question of the study, the students were given 'Writing Part' of 'Preliminary English Test (PET)' to test their language proficiency level. 100 students (all students of Inter Part II of session 2014-2016) participated in the test. PET consisted of three parts. Part one was about sentence formation. Part two was about short communicative message and part three was about letter or story composition. The basic focus of all the parts was expository writing skill. The students were awarded marks and then mean score was taken. Selection of an average sample based on mean score one standard deviation above and one standard deviation below the mean score. Later these groups were again equated through scores of pretest.

\section{Analysis of Pretest Scores}

Pretest was conducted on the sample to ensure second research question and results of the two groups were equated on the basis of pretest scores. 
Table 3

Equivalence of Experimental and Control Group on the Basis of Mean Score of Pretest

Experimental Group Control Group

$14.60 \quad 15.25$

Both the groups score almost equal as shown in table 31. This suggests that the sample randomly assigned into control and experimental groups was equal before starting the experiment.

\section{Comparisons of Mean Score of Groups on the Basis of Pretest}

When the groups were formed and equated, their results in pretest were also measured by applying t-test.

Table 4

Results of t-test of Overall Scores of Control and Experimental Groupin Pretest

\begin{tabular}{lllllllll}
\hline & Group & $\mathrm{N}$ & Mean & $\mathrm{SD}$ & $\begin{array}{l}\text { Std. } \\
\text { Error }\end{array}$ & $t$-value & $d f$ & $\begin{array}{l}\text { Sig. } \\
\text { tailed) }\end{array}$ \\
\hline \multirow{2}{*}{ Pretest } & Control & 20 & 15.25 & 2.337 & .523 & .965 & 38 & .341 \\
& Experimental & 20 & 14.60 & 1.903 & .426 & .965 & \\
\hline
\end{tabular}

Experimental: concept mapping

Level of Significance: 0.05

As per Independent Sample t-test for pretest scores, the significant value is .341 that is more than 0.05 which reveals that there was no significant difference between subjects of control and experimental (Concept Mapping) group at the start of experiment implying the equivalency of both the groups.

\section{Comparison of Groups on the Basis of Scores Obtained through Posttest}

The major and third research question of the study was to investigate the effects of concept mapping on expository writing skill for students at Intermediate level. The question was ensured through administration of posttest to both control and Experimental groups. Initially, descriptive statistics was computed for the performance of participants of both the groups. Table 5 shows the basic descriptive statistics including mean score and standard deviation of control and experimental groups. 
Table 5

Mean Score of Posttest by both Groups

\begin{tabular}{lllll}
\hline & Participant's Group & Mean & N & Std. Deviation \\
\hline & Control & 15.90 & 20 & 2.100 \\
& & & & \\
Posttest & Experimental C-Map & 20.45 & 20 & 1.877 \\
\hline
\end{tabular}

The comparison of mean score of the posttest shows that the participants of experimental group performed better than that of the control group. In other words the performance of the control group is lower than that of the experimental group.

\section{Comparison of the Groups on the Basis of Scores Obtained through Pretest and Posttest}

The comparison of groups was made by analyzing pretest posttest mean score differences applying t-test on different groups of the study.

Table 6

Comparison of Difference of Mean Scores of Control Group and Experimental (concept mapping) Group in Pretest and Posttest

\begin{tabular}{lllllll}
\hline Group & $\mathrm{N}$ & Mean & $\begin{array}{l}\text { Std. } \\
\text { Deviation }\end{array}$ & $d f$ & $t$-value & Sig. \\
\hline Control & 20 & .65 & 2.084 & & & \\
Experimental & 20 & 5.85 & 1.268 & 38 & -9.532 & .000
\end{tabular}

$* \mathrm{p}<0.05$.

To explore the significant difference in the performance of the control and experimental groups in pretest and posttest, an independent sample ttest was used. The mean of difference of Control Group is .65 and mean of the Experimental Group concept mapping is 5.85. The Standard Deviation of both the groups is also significantly different. The results $(.000<.05)$ indicated the meaningful difference between the groups.So the null hypothesis is rejected that there is no difference in the mean score of posttest of control and experimental concept mapping groups.

\section{Discussions}

In present era, many strategies have got importance for teaching 
language skills. As English has got an international language status, its teaching and learning is also of utmost importance. In Pakistan, new techniques and strategies are being introduced to keep pace with the international standards of teaching. To enhance the quality education, new and different researches have also been carried out in countries where English is non-native language. The researcher has tried to add to a greater bulk of information and contributed her share through empirical evidences. English language is based on four basic skills i. e Listening, Speaking, Reading and Writing. The researcher focused on writing skill and selected Expository Writing as a dependent variable to see the impact of concept mapping strategies.

The findings of the study suggested that achievements of students in writing expositions are more observable when they are taught through strategies enabling them to organize task in the form of concept mapping. Similar results have been found by Talebinezhad and Negari (2007) who investigated the effects of concept mapping on self-regulation of the students with reference to writing skill.

The study aimed to improve writing skill of the students in English language classrooms with the help of concept mapping strategies. Similarly, in the study byMeghyasi and Hashamdar (2015) the effects of concept mapping strategies were investigated on Iranian EFL Learners' descriptive and persuasive writing. The results of present study are also consistent with that of the research conducted by Ojima (2006) who investigated the effect of concept mapping on Japnese ESL writers as pre task planning and the results of case study proved the use of concept mapping as influential strategy for improving writing skill of the learners. Lin (2003) contributed in the same area of research by investigating the effects of computer based concept mapping on the prewriting ability of middle school students and suggested the positive effects of concept mapping on the writing skills of the students.

In a study conducted in Iran by Fahim and Rahimi (2001) the effects of concept mapping strategy were seen on the writing performance of EFL learners. The results confirmed that use of concept mapping strategy can improve writing skill.

Cheema and Mirza (2015) made quasi experimental research to analyze the effects of concept mapping on academic performance of the students. The students taught through concept mapping performed better in the subject of science according to the results of the study.

The results of experiment indicated that students taught through concept mapping remained enthusiastic throughout the intervention course. On the whole their writings were beautifully organized and systematically 
developed. The control group was very energetic at the beginning. As the students were unaware of the grouping purpose, they did not know about writing prompts. Some of the students also tried to perform better but on the whole the essays were almost copied from the helping material and students' guides and notes. Nothing new was added in from their own lives. The content, development of ideas, organization and convention everything was a memorized production. Although some students added a few quotations too but could not match with the other group's writings which were genuine in thought and appealing in selection of words. The students had potential to do better but could not do so as they were not guided for that and taught in a traditional way. At the end of experiment, when they came to know about the differences in groups and teaching methodology of other group, they wished to have been in other group instead of their own.

The results indicated that the participants developed their writing skill by using concept mapping strategy. They learnt to write systematically. They became more organized in their writing following cohesion and coherence. The concept mapping helped them to organize their thoughts first on the paper and then to create links between different concepts on the same topic. Every participant tried according to her own creativity to follow the links given for writing task. This exercise also encouraged motivational spirit. Thus experimental group resulted in more organized and rich writing performance than the results of traditional methods of teaching writing.

The results and findings of other researches validate the results of the study which indicate that there is strong cause and effect relationship between dependent and independent variables. Concept mapping has relationship with Expository writing skill. The results imply that concept mapping strategy is the factor that impacts expository writing skill of the students. It is evident through results that concept mapping impact students' expository writing skill positively and creates chances for creative and quick learning. The results also imply that without and concept mapping, the writing task becomes burdensome for students and they are encouraged to rote learning that hinders the development of thinking skills.

\section{Conclusions}

The findings of the study led to the conclusions that students of Intermediate Part II were proved of the same proficiency level at the beginning of the study. But when they underwent the intervention course, 
the students of Experimental Group taught through concept mapping performed better results in posttest as compared to those of the control group. The students of Control group taught through traditional method did not show any remarkable differences in posttest scores as compared to those of the experimental group. The present study just focuses on specific strategy of concept mapping for improvement of specific skill i.e. expository writing skill in context of ELT in Pakistan. Even then it contributes meaningfully to the present literature. The research results, findings and discussions reveal that concept mapping is useful for teaching expository writing skill. Teachers should also be trained in this regard to develop their capabilities and teaching styles.

Due to time limitation, only female students from government sector were selected by the researcher to see the effects of concept mapping only on expository writing skill. The researcher believes that research in broader horizon can be conducted with another research design to see the effects of concept mapping in comparison of public private sector and in the achievement of girls and boys by the future researchers. 


\section{References}

Ahangari S., \& Behzady, L. (2011). The effect of explicit teaching of concept maps on Iranian EFL learners' writing performance. American Journal of Scientific Research, 61, 100-112

Ausubel, D. P. (1963). The psychology of meaningful verbal learning. A Cognitive View. New York, NY: Holt Rinehart and Winston.

Bharambe, M. I. (2012). Effectiveness of mind mapping in educational psychology. Journal of Biological Chemistry, 2, 10-18.

Brown, H. D. (2000). Principles of language learning and teaching. $\left(4^{\text {th }}\right.$ ed.) New York: Longman.

Buzan, T. (2010). Buku Pintar Mind Mapping Untuk Anak. Jakarta: PT Gramedia Pustaka Utama

Chen, Y. (2007). Learning to learn: the impact of strategy training. ELT Journal, 61(1),

Deshatty, D. D., \& Mokashi, V. (2013). Mind maps as a learning tool in anatomy. International Journal of Anatomy and Research, 1, 100103.

Fahim, M., \& Rahimi, A. H. (2011). The effect of concept mapping strategy on the writing performance of EFL learners. Journal of Academic and Applied Studies, 1(5), 1-8.

Firmansyah, A. (2015). The influence of mind mapping technique and students' attitude toward students' ability in writing a recount text of the eighth grade students of State Junior High School 45 Palembang. Ripteksi KependidiKan PGRI, 2(1), 11-18

Gay, L. R. (1995). Educational Research: Competencies for Analysis and Application. (5 $5^{\text {th }}$ ed) $4^{\text {th }}$ Reprint $(2000)$ by National Book Foundation. Islamabad: Allama Iqbal Open University.

Keleş, Ö. (2012). Elementary teachers' views on mind mapping. International Journal of Education, 4, doi:10.5296/ije.v4i1.1327

Kyoko, I., \& Hiroko, T. (2011). A study on the effect of hierarchical concept mapping on writing by junior high school students. Bulletin of the Faculty of Education 59(1), 223-228.

Lee, Y. (2013). Collaborative concept mapping as a pre-writing strategy 
for 12 learning: A Korean Application. International Journal of Information and Education Technology, 3(2), 254-258.

Lin, S.Y., Strickland, J., Ray, B., \& Denner, P. (2004). Computer based concept mapping as a prewriting strategy for middle school students. A Middle School Computer Technologies Journal, 7 (2).

Liu, P., Chen C., Chang, \& Yu-Ju (2010). Effects of a computer-assisted concept mapping learning strategy on EFL college students' English reading comprehension. Computers and Education, 54, 436-445.

Maghsoudi, M., \& Haririan, J. (2013). The impact of brainstorming strategies Iranian EFL learners writing skill regarding their social class status. Journal of language and linguistics, 1, 60-67. doi:10.11648/j.ijl1.s.20130101.20

Meghyasi, M \& Hashamdar, M (2015). The effect of concept mapping strategies on Iranian EFL learners' descriptive and persuasive writing. International Journal of Educational Investigations, 2 (7), 57-68.

Ministry of Education. Government of Pakistan. (2006). National Curriculum for English Language I-XII. Islamabad. Ministry of Education.

Muhib, A., Anggani LB, D., \& Hartono, R. (2014). Mind mapping and everybody writes techniques for students with high and low writing achievement. English Education Journal, 4, 99-105.

Negari, G. M. (2011). A study on strategy instruction and efl learners' writing skill. International Journal of English Linguistics,1(2), 299307

Novak, 1. D., \& Gowin, D. B. (1984). Learning how to learn. New York, NY: Cambridge University Press.

Ojima, M. (2006). Concept mapping as pre-task planning: A case study of three Japanese ESL writers. Journal of Science Direct System, 34, $566-585$.

Pishghadam, R., \& Ghanizadeh, A. (2006). On the impact of concept mapping as a prewriting activity on EFL learners' writing ability. Iranian journal of Applied Linguistics, 9 (2), 101-126. 
Rao, Z. (2007). Training in brainstorming and developing writing skills. ELT Journal, 61(2), 100-106.

Saed, H. A., \& AL-Omari, H. A. (2014). The effectiveness of a proposed program based on a mind mapping strategy in developing the writing achievement of eleventh grade EFL students in Jordan and their attitudes towards writing. Journal of Education and Practice, 5, 88109.

Siddiqui, S. (2010). Rethinking education in Pakistan: Perceptions, practices and possibilities. Karachi: Paramount Publishing Enterprise.

Talebinezhad, M. \& Mousapour Negari, G. (2007). The effect of explicit teaching of concept mapping in expository writing on EFL students' self-regulation. The Linguistic Journal, 2(1), 69-90.

Vakilifard \& Armand (2006). The effects of 'concept mapping' on second language learners' comprehension of informative text. In: A. J. Cañas, j. D. Novak, eds. Concept maps: theory, methodology, technology proceedings of the second int. conference on concept mapping. San josé, costa rica.

Vanides, J., Yin, Y., Ruiz-Primo, M. A., Ayala, C. C., \& Shavelson, R. J. (2005). Comparison of two concept-mapping techniques: Implications for scoring, interpretation, and use. Journal of Research in Science Teaching, 42(2), 166-184.

\section{Citation of this Article:}

Rahman, R., \& Ambreen, M. (2018). Concept mapping for improving expository writing in second language. Pakistan Journal of Education, $35(2), 17-36$.

Received on: May 19,2017

Revised on: March 12, 2018

Accepted on: July $\quad 10,2018$ 